\title{
Analisis Strategi Promosi Program Sahabat Wakaf pada Lembaga Gerakan Wakaf Indonesia (GWI) Sidoarjo, Jawa Timur
}

\author{
Khoirul Fathoni \\ Institut Agama Islam Negeri Ponorogo, Indonesia \\ khoirulfathoni@iainponorogo.ac.id \\ Lia Nor Anila \\ Universitas Islam Negeri Sunan Ampel Surabaya, Indonesia \\ lianuranila23@gmail.com
}

\begin{abstract}
:
This study seeks to reveal a waqf asset marketing strategy model through a program that is eaten with the Friends Program Promotion. The main target of this activity is community, that is, by referring to the hypothesis that waqf assets can develop if supported by human resources, one way is to use waqf assets to be owned by everyone, both as partners and ambassadors. The reason is that the waqf assets are not well known by the public so that many waqf assets are not managed. In addition, the waqf assets contain more certificate conflicts because they have not been properly recorded by the waqf institution. Therefore, this study wants to offer a strategy to promote the development of waqf assets. This research is qualitative with a descriptive approach. Data collection techniques are through observation, interviews, audio and visual media and literature review. The results of the research that have been carried out are as follows: (1) the Indonesian Waqf Movement institute in carrying out a promotion strategy for the waqf companions program, namely by informing and introducing this waqf companion program through printed media (brochures, pamphlets and magazines) and the internet (Instagram, Twitter, Facebook and WhatsApp), (2) in implementing the promotion strategy of the waqf companions program, the Indonesian Waqf Movement institute collaborated with various well-known campuses by holding seminars on endowment companions, (3) promotions that have been formulated and implemented are running quite well, although there are still some a factor that becomes a barrier but this can be a note for the Indonesian Waqf Movement institution in carrying out promotional strategies in the future.
\end{abstract}

Keywords: Promotion Strategy, Waqf, Waqf Insitution 


\section{Latar Belakang}

Bukan hanya di Indonesia, bahkan di kancah global, lembaga wakaf menjadi lembaga filantropi Islam yang mampu berjajar dengan lembaga berbasis keuangan lainnya. Selain menjamur di setiap negara, peran lembaga wakaf memberikan sumbangsih yang sangat besar terhadap perekonomian masyarakat, baik mikro maupun makro. Wajar kemudian, jika banyak problem sosial berbasis ekonomi masyarakat yang terbantukan dengan adanya lembaga wakaf. Begitupun di Indonesia, lembaga-lembaga wakaf beraktivitas sesuai manajemen masing-masing untuk menyelesaikan masalah kemiskinan. Dengan fenomena demikian, Indonesia memiliki potensi yang sangat besar dalam menghimpun, membangun, serta mengembangkan dana wakaf.

Tetapi kurangnya kesadaran dan dukungan dari berbagai lembagalembaga swasta yang ada serta pemerintah sehingga dana wakaf tidak terhimpun secara maksimal. Jika saja lembaga-lembaga swasta dan pemerintah bersatu, bahu-membahu dan saling memberikan dukungannya dalam mempromosikan gerakan wakaf. Selain itu masih banyak masyarakat yang belum sadar akan kehadiran dan pentingnya wakaf bagi pembangunan ekonomi umat muslim di indonesia. ${ }^{1}$ Diseluruh dunia hanya indonesia yang memiliki jumlah umat islam terbanyak, hal tersebut merupakan aset besar untuk menghimpun, membangun serta mengembangkan dana wakaf.

Saat telah disahkannya undang-undang tentang perwakafan yaitu UU No. 41 tahun 2004. Gerakan wakaf yang ada di Indonesia mengalami kemajuan yang sangat pesat, yang awalnya konsumtif menjadi produktif atau bisa dibilang yang awalnya tidak profesional menjadi profesional. Hal ini merupakan dampak postitif dan juga awal untuk melakukan gerakan wakaf untuk memanfaatkan potensi yang besar dalam menghimpun dan mengembangkan wakaf. $^{2}$ Kondisi ini jauh lebih berkembang dari sebelumnya. Dilihat dari potensi yang besar, hal mendasar yang menentukan dan menjalankan sebuah organisasi adalah strategi penghimpunan dana wakaf di setiap lembaga wakaf. Semua yang dilakukan tidak hanya untuk kesejahteraan masyarakat, tetapi juga untuk

\footnotetext{
${ }^{1}$ Problematika wakaf di Indonesia menyangkut tentang kesadaran masyarakat, manajemen asset wakaf dan sumber daya yang belum professional. Lihat lebih jelas dalam Fahmi Medias, "Bank Wakaf: Solusi Pemberdayaan Sosial Ekonomi Indonesia", Indonesian Journal of Islamic Literature and Muslim Society, 2,1(2017): 61-84.

${ }^{2}$ Lihat Khalifah Muhammad Ali; Meida Yuliani; Sri Mulatsih; Zaki Abdullah, "Aspek-Aspek Prioritas Manajemen Wakaf di Indonesia", AL-FALAH: Journal of Islamic Economics, 3, 1(2018): 1-26
} 
pengembangan dan revolusi kebijakan serta perubahan pranata kehidupan di masyarakat. ${ }^{3}$

Dalam agama islam dianjurkan untuk setiap umat muslim di dunia untuk selalu beramal dan berbagi kepada yang membutuhkan. Hal tersebut menumbuhkan kecendrungan umat islam untuk selalu beramal. Terbukti dengan terjadinya peningkatan dari tahun ke tahun melalui kegiatan keagamaan dalam rangka pemungutan dana ZIS termasuk dana wakaf. Indonesia dengan negara yang hampir seluruh penduduknya adalah umat muslim merupakan peluang besar menjadi calon wakaf terproduktif. ${ }^{4}$

Dari hasil survey yang dilakukan hampir deluruh dana wakaf yang diperoleh berasal dari wakaf perorangan. ${ }^{5}$ Hal ini terjadi karena wakaf merupakan salah satu cara bagi umat muslim untuk mendekatkan diri kepada Allah swt. Selain itu ada juga yang ingin namanya terus dikenal dengan mengeluarkan sebagian harta bendanya untuk diwakafkan, biasanya yang melakukan hal ini adalah orang-orang kaya. Pemerintah juga ikut andil dalam menyumbangkan harta wakaf yang beredar dimasyarakat.

Tingginya sumber harta wakaf perorangan sehingga menjadikannya sebagai target yang diutamakan oleh nadzir. Namun, ada juga yang menargetkan perusahaan dan perorangan sekaligus. Strategi promosi merupakan salah satu strategi yang cocok untuk melakukan dua hal ersebut. Dalam suatu lembaga pengelola zakat dan wakaf untuk menarik ataupun memepertahankan muzakki/wakif, salah satu cara yang ampuh yaitu melakukan promosi. Tujuan promosi adalah memberikan informasi tentang produk yang ditawarkan kepada pelanggan dan untuk menarik calon pelanggan baru, dengan promosi kita dapat mempengaruhi pelanggan yang akhirnya tertarik dan membeli produk yang ditawarkan. ${ }^{6}$ Selain itu promosi juga dapat meningkatkan citra yang baik bagi sebuah lembaga.

Senada dengan fakta diatas, lembaga Gerakan Wakaf Indonesia dengan bekerja sama dengan Generali perusahaan asuransi membuat program baru yaitu sahabat wakaf. Melalui program ini lembaga Gerakan

\footnotetext{
3 Burhanudin Mukhamad Faturahman, "Kepemimpinan dalam Budaya Organisasi”, Madani: Jurnal Politik dan Sosial Kemasyarakatan, 10, 1(2018): 1-11.

${ }^{4}$ Hida Hiyanti; Indria Fitri Afiyana; Siti Fazriah, "Potensi dan Realisasi Wakaf Uang di Indonesia Tahun 20154-2018”, Jurnal Ilmiah MEA (Manajemen, Ekonomi, \& Akuntansi), 4, 1(2020): 7784.

5 Lihat dalam penelitiaannya Aam Rusydiana dan Solihah S. Rahayu, "Bagaimana Strategi Pengembangan Wakaf Tunai di Indonesia”, Jurnal Ekonomi dan Bisnis Islam, 5,1(2019): 15-33.

${ }^{6}$ Indri Yuliafitri; Arie Indra Rivaldi, "Pengaruh Penerapan Prinsip-Prinsip Good Governance dan Promosi terhadap Penerimaan Wakaf Tunai (pada Lembaga Pengelola Wakaf di Indonesia)", Jurnal InFestasi, 13, 1(2017): 217-226.
} 
Wakaf Indonesia mengupayakan untuk mengembangkan training Sahabat Wakaf. Dan juga program Sahabat Wakaf ini menerima respons yang baik dari seluruh mahasiswa atau mahasiswi yang dijaring melalui program training sahabat wakaf, telah berkontribusi bagi masa depan mahasiswa/mahasiswi dalam pendidikan. ${ }^{7}$ Program sahabat wakaf yang merupakan pelaku promosi yang diakomodasi oleh lembaga Gerakan Wakaf Indonesia yang berupaya untuk mengoptimalisasikan harta wakaf dengan mempromosikan program sahabat wakaf yang akan membantu masyarakat untuk berwakaf.

Sesuai dengan penjelasan diatas, karena itu penulis tertarik untuk melakukan penelitian tentang strategi promosi yang dilakukan oleh lembaga Gerakan Wakaf Indonesia melalui program sahabat wakaf dalam bentuk Karya Tulis Ilmiah yang berjudul "Analisi Strategi Promosi Program Sahabat Wakaf Pada Lembaga Gerakan Wakaf Indonesia (GWI) Sidoarjo, Jawa Timur".

\section{Metode Penelitian}

Penelitian ini bersifat kualitatif, dengan pendekatan deskriptif analisis strategic. Sifat deskriptif disini adalah mengumpulkan data atau informasi tentang obyek yang diteliti sampai jenuh. Lokasi penelitian diambil di Lembaga Gerakan Wakaf Indonesia (GWI) yang berlokasi di Jl. Taman Paris Raya No.1, Kec. Gedangan, Sidoarjo. Pemilihan lokasi didasarkan pada beberapa pertimbangan, yaitu 1) satu-satunya lembaga wakaf yang menerapkan program promosi wakaf, 2) belum pernah ada yang meneliti kesana, dan 3) prestasi pengembangan wakaf disana yang terbilang efektif.

Sementara sumber data, menurut Lofland (1984) dalam penelitian kualitatif sumber data utamanya ialah kata-kata, dan tindakan, selebihnya adalah data tambahan seperti dokumen dan lain-lain. ${ }^{8}$ Kata-kata dan tindakan orang-orang yang diamati atau diwawancarai merupakan suber data utama yang dicatat melalui catatan tertulis atau melalui perekaman video/audio, pengambilan foto, atau film. ${ }^{9}$

Teknik pengumpulan data. yang digunakan sebagai bahan penelitian adalah: 1) observasi, merupakan bagian yang sangat penting

\footnotetext{
${ }^{7}$ Lihat dalam https://gerakanwakaf.id/ diakses tanggal 26 Februari 2021.

${ }^{8}$ Cik Hasan Bisri, Pilar-Pilar Penelitian Hukum Islam dan Pranata Sosial (Jakarta : Grafindo Persada, 2004), 56.

${ }^{9}$ Sampel bertujuan dicirikan dengan : (1) rancangan sampel yang muncul tidak dapat ditentukan dan ditarik terlebih dahulu; (2) pemilihan sampel dilakukan secara berurutan; (3) penyeseuaian berkelanjutan dari sampel; dan (4) pemilihan berakhir jika sudah terjadi pengulangan. Lihat Lexy J. Meleong, Metodologi Penelitian Kualitatif Edisi Revisi, Cet. Ke-22 (Bandung : PT REMAJA ROSDAKARYA, 2006), 225.
} 
dalam penelitian kualitatif. Dengan observasi peneliti dapat mendokumentasikan dan merefleksi secara sistematis terhadap kegiatan dan interaksi subjek penelitian. Observasi pada penelitian ini dilakukan secara terstruktur, yaitu pengamatan dilakukan secara sistematik, karena peneliti telah mengetahui aspek-aspek yang relevan dengan masalah dan tujuan penelitian. ${ }^{10}$ 2) wawancara, maksud mengadakan wawancara adalah menanyakan secara langsung kepada narasumber tentang obyek penelitian yang sedang diteliti. ${ }^{11}$ Selain itu, wawancara pada penelitian ini dilakukan untuk mengajukan beberapa pertanyaan yang berhubungan dengan obyek penelitian. Wawancara merupakan metode pengumpulan data yang dilakukan dengan mendapatkan keterangan atau pendapat dari seorang responden dengan tanya jawab tatap muka secara langsung. 3) materi audio dan visual. Data ini dapat berupa rekaman baik suara maupun gambar dan hasil cetakan seperti gambar, foto, dan lain sebagainya. ${ }^{12}$

Teknik Analaisi Data. Pada penelitian ini, penulis menggunakan metode analisis kualitatif. Menurut John W. Creswell (1998) menjelaskan bahwa penelitian kualitatif adalah sebuah proses penyelidikan, pemahaman didasarkan pada perbedaan tradisi-tradisi metodologis pada penelitian yang menjelaskan permasalahan sosial atau manusia. Peneliti menjelaskan sebuah tempat, gambaran holistik, analisis kata-kata, laporan secara detail menurut sudut pandang informan dan perilaku studi alam seting alamiah. ${ }^{13}$ Menarik Kesimpulan. Setelah melakukan berbagai analisis dan perbandingan data-data yang sudah terkumpul. Langkah terakhir adalah menarik kesimpulan dari data-data informasi yang sudah didapatkan, mengambil kesimpulan-kesimpulan final terkait objek yang diteliti.

\section{Hasil Penelitian}

\section{Sepintas Gerakan Wakaf Indonesia}

Program sahabat wakaf merupakan salah satu bagian dari program kerja yang dilaksanakan oleh lembaga Gerakan Wakaf Indonesia (GWI) yang bekerja sama dengan berbagai lembaga pendidikan perguruan tinggi antara lain Universitas Airlangga, Universitas Islam Negeri Sunan Ampel, Universitas Trunojoyo Madura, dan Universitas Nahdlatul Ulama. selain itu GWI juga melakukan terobosan lain yang bekerja sama dengan

\footnotetext{
${ }^{10}$ Burhan Bungin, Penelitian Kualitatif : Komunikasi, Ekonomi, Kebijakan Publik, dan Ilmu Sosial lainnya (Jakarta: Kencana Prenada Media Group), 108.

${ }^{11}$ Ibid., 109.

${ }^{12}$ Sugiyono, Metode Penelitian Kuantitatif Kualitatif dan $R \&$ D (Bandung: Alfabeta, 2014), 246.

${ }^{13}$ John W. Creswell, Research Design, Qualitative, Quantitative and Mixed Methods Approaches, Trans, (Yogyakarta: Pustaka Pelajar, 2016), 105.
} 
lembaga keuangan syariah untuk memudahkan transaksi wakaf tunai yang ringan dengan mudah, dengan tujuan untuk menyadarkan masyarakat bahwa berwakaf tidak harus dengan aset yang besar seperti tanah, bangunan dan lainnya. ${ }^{14}$

Peran GWI, juga mengingatkan mengenai potensi wakaf yang sangat besar untuk membantu peningkatan ekonomi di indonesia, dengan ini GWI berharap agar masyarakat mau berwakaf dengan cara wakaf tunai, yang nantinya dari dana wakaf tunai akan dipergunakan untuk memproduktifkan lahan wakaf yang kurang produktif karena hambatan biaya operasional. Melalui program sahabat wakaf diharapkan dapat membantu lembaga GWI melakukan dakwah atau siar kepada masyarakat mengenai manfaat dan besarnya potensi wakaf guna kemajuan ekonomi umat muslim di indonesia. ${ }^{15}$

Pelaksanaan program sahabat wakaf memiliki beberapa tahapan seperti tahap seleksi kemudian tahap ujian bagi calon peserta sahabat wakaf. Lembaga Gerakan Wakaf Indonesia (GWI) melakukan tahapantahapan tersebut merupakan salah satu upaya untuk mendapatkan dan membina calon sahabat wakaf yang memenuhi target.

\section{Aspek Hukum Wakaf Produktif dan Wakaf Tunai}

Sebelum memasuki penjelasan mengenai strategi yang digunakan lembaga Gerakan Wakaf Indonesia untuk mempromosikan program sahabat wakaf, penulis akan membahas dari segi aspek hukumnya. Di penjelasan sebelumnya disebutkan mengenai wakaf produktif dan wakaf tunai, jadi penulis akan membahas mengenai aspek hukum wakaf produktif dan wakaf tunai.

Wakaf produktif adalah salah satu skema pengelolaan wakaf yang bertujuan untuk meningkatkan surplus dari aset wakaf itu sendiri, sehingga dari hasil surplus dana wakaf produktif tersebut akan digunakan untuk pembiaayaan ekonomi umat seperti dalam bidang pendidikan dan kesehatan. ${ }^{16}$ Problematika yang menjadi hambatan wakaf produktif adalah kesadaran masyarakat akan wakaf benda bergerak seperti uang atau surat berharga. Masih banyak sebagaian masyarakat yang mewakafkan hartanya berupa benda tidak bergerak seperti tanah

14 lihat dalam "tentang GWI", dalam https://gerakanwakaf.id/tentanggwi/\#: :text=Gerakan\%20Wakaf\%20Indonesia\%20(GWI)\%20adalah,sekaligus\%20menjalankan \%20bisnis\%20berbasis\%20syariah. Diakses tanggal 25 Februari 2021.

15 Ali Hamdan, Wawancara (Sidoarjo, 25 Februari 2021) Ali Hamdan adalah Sekretaris Jenderal Gerakan Wakaf Indonesia.

${ }^{16}$ Lokot Zein Nasution; Diba Anggraini Aris, "Konstruksi Pengembangan Wakaf Saham dalam Rangka Mengoptimalkan Potensi Wakaf Produktif di Indonesia", Islamic Circle, 1,1(2020): 115. 
dan bangunan, dimana untuk pengelolaannya membutuhkan dana operasional yang besar agar dapat digunakan secara abadi, namun pada kenyataannya hingga saat ini masih banyak tanah wakaf yang dikelola secara konsumtif seperti dibangun untuk kegiatan ibadah, sehinnga banyak tanah wakaf yang terbengkalai karena minimnya dana untuk operasional tanah wakaf tersebut.

Tugas besar nazhir saat ini adalah memberikan kesadaran masyarakat terkait keberadaan wakaf produktif atau wakaf uang dan surat berharga lainnya, menjelaskan bahwa wakaf produktif memiliki manfaat yang sangat besar dan juga dapat meningkatkan surplus investasi wakaf. Jika wakaf produktif mulai meningkat, maka akan banyak lahan wakaf yang terbengkalai dapat dikelola lagi untuk sarana dan kegiatan yang memiliki profit tinggi seperti sekolah dan rumah sakit. Selain biaya operasional yang terus berjalan, pembangunan sekolah dan rumah sakit akan bermanfaat bagi masyarakat. ${ }^{17}$ Peningkatan wakaf produktif sama halnya dengan peningkatan ekonomi umat.

Undang-Undang No.41 Tahun 2004 Pasal 22 tentang peruntukan wakaf menyebutkan bahwa dalam rangka mencapai tujuan dan fungsi wakaf, benda wakaf hanya dapat diperuntukkan bagi : (a) sarana dan kegiatan ibadah, (b) sarana dan kegiatan pendidikan serta kesehatan, (c) bantuan kepada fakir miskin, anak terlantar, yatim piatu, beasiswa, (d) kemajuan dan peningkatan ekonomi umat, dan/atau (e) kemajuan kesejahteraan umum lainnya yang tidak bertentangan dengan syariah dan peraturan perundang-undangan. ${ }^{18}$

Dari UU No. 41 Tahun 2004 tersebut dapat ditarik kesimpulan bahwa dalam pengelolaan wakaf tidak hanya terbatas pada sarana dan kegiatan ibadah, tetapi bisa untuk sarana dan kegiatan lain asalkan tidak menyimpang dari aturan syariah dan perundang-undangan. Jadi untuk pengelolaan wakaf agar lebih produktif adalah dengan cara membangun sarana dan kegiatan yang produktif seperti bidang pendidikan, kesehatan dan lain sebagainya, dengan melakukan strategi pengelolaan ini maka pembangunan ekonomi umat muslim di indonesia akan semakin maju dan berkembang pesat.

Wakaf tunai merupakan wakaf dalam bentuk uang atau surat berharga. Wakaf tunai diatur dalam Undang-Undang No.41 Tahun 2004 Pasal 28,29,30 dan 31 tentang wakaf benda bergerak berupa uang. Pasal 28 berbunyi bahwa wakif dapat mewakafkan benda bergerak berupa uang

17 Umi Ghozilah; Eka Khumaidatul Khasanah, "Manajemen Wakaf Produktif dalam Pemberdayaan di KSPPS BMT Bina Umat Sejahtera Lasem Rembang", Management and Werment Journal, 2, 2(2020): 151-163.

${ }^{18}$ Rahmat Dahlan, "Analisis Kelembagaan Badan Wakaf di Indonesia", ESENSI: Jurnal Bisnis dan Manajemen, 6, 1(2016): 31-25. 
melalui lembaga keuangan syariah yang ditunjuk oleh menteri. Dalam pasal tersebut dengan jelas dikatakan bahwa wakif bisa berwakaf dalam bentuk uang dan tidak hanya terbatas pada wakaf aset berharga seperti tanah dan bangunan. ${ }^{19}$ Problematika yang masih sering terjadi hingga saat ini adalah pemahaman masyarakat yang masih jauh mengenai wakaf tunai, dan masih beranggapan kalau wakaf identik dengan aset-aset berharga seperti tanah dan bangunan. Hal tersebut yang menjadi tugas besar bagi para amil untuk memberikan pemahaman kepada masyarakat mengenai wakaf tunai.

Pasal 29 berbunyi; (1) Wakaf benda bergerak berupa uang sebagaimana dimaksud dalam Pasal 28 dilaksanakan oleh Wakif dengan pernyataan kehendak Wakif yang dilakukan secara tertulis. (2) Wakaf benda bergerak berupa uang sebagaimana dimaksud pada ayat (1) diterbitkan dalam bentuk sertifikat wakaf uang. (3) Sertifikat wakaf uang sebagaimana dimaksud pada ayat (2) diterbitkan dan disampaikan oleh lembaga keuangan syariah kepada Wakif dan Nazhir sebagai bukti penyerahan harta benda wakaf. Wakaf benda bergerak atau wakaf uang yang sering disebut sebagai wakaf tunai dilaksanakan oleh wakif yang diakukan secara tertulis dilembaga wakaf. ${ }^{20}$ Wakif yang berwakaf tunai akan mendapatkan sertifikasi wakaf tunai yang diterbitkan oleh lembaga keuangan syariah yang sudah ditunjuk oleh menteri.

Pasal 30 berbunyi; Lembaga keuangan syariah atas nama Nazhir mendaftarkan harta benda wakaf berupa uang kepada Menteri selambatlambatnya 7 (tujuh) hari kerja sejak diterbitkannya Sertifikat Wakaf Uang. Dari pasal 30 diketahui bahwa pelaporan terkait harta benda yang diwakafkan oleh wakif kepada menteri dilakukan setelah sertifikat uang terbit. Setelah pelaporan kepada menteri, maka hart benda atau uang yang awalanya menjadi milik wakif berpindah kepemilikan menjadi aset wakaf yang akan digunakan sebagai biaya operasional pengelolaan wakaf produktif. ${ }^{21}$

Adanya program sahabat wakaf yang membina calon nazhir untuk masa depan perwakafan indonesia, diharapkan dapat membantu mensyiarkan kepada masyarakat luas mengenai wakaf tunai serta memberikan pemahaman dan penjelasan bahwa berwakaf saat ini sangat

\footnotetext{
19 Muhammad Faisal, "Sikap, Norma Subyektif, Religuisitas dan Partisipasi terhadap Wakaf Tunai, Li Falah: Jurnal Studi Ekonmi dan Bisnis Islam, 4,1(2019): 235-250.

20 M. Cizakca, "Ottoman Cash Waqfs Revisted: the Cas of Bursa 1555-1823", Journal of Economic and Social History of the Orient, 38, 3(2013): 313-354.

21 Agung Minto Wahyu; Navillah Laila Wardani, "Wakaf Uang Digital untuk Milenial: Pemanaatan Bonus Demografi Melalui Aplikasi Wakaf Uang Digital untuk Mengembangkan Industri UMKM Halal”, el-Aswaq, 1, 1(2020): 17-22.
} 
mudah dan ringan karena wakaf tidak hanya terbatas pada wakaf tanah dan bangunan melainkan dengan uang masyarakat sudah bisa berwakaf.

\section{Formulasi strategi promosi di Lembaga Gerakan Wakaf Indonesia}

Kegiatan promosi sangatlah penting dalam suatu organisasi guna memperkenalkan produknya kepada masyarakat luas. Promosi ini bertujuan untuk memberikan informasi kepada masyarakat tentang produk yang ditawarkan supaya mereka mengetahui dan tertarik kepada produk kita, sehingga menimbulkan keputusan untuk membeli. ${ }^{22}$

Sebelum melakukan promosi terkait produk yang akan kita tawarkan, langkah awal yang harus dilakukan yaitu membuat rencana atau formulasi promosi supaya dapat mencapai target yang telah ditentukan dan mencapai tujuan. formulasi promosi yang dilakukan oleh lembaga Gerakan Wakaf Indonesia yaitu strategi bauran promosi. Menurut Kotler dan Armstrong, bauran promosi adalah perpaduan khusus antara iklan, penjualan pribadi, promosi penjualan, dan hubungan masyarakat yang dipakai oleh sebuah lembaga atau perusahaan untuk mencapai tujuan iklan dan pemasarannya. Formulasi strategi promosi dengan menganalisis dan mengkombinasikannya dengan hal-hal yang ada dalam bauran promosi antara lain: Advertising (periklanan), personal selling, Promosi Penjualan dan Hubungan masyarakat (publicity) serta pemasaran langsung (Direct Marketing). ${ }^{23}$

Pertama Advertising (Periklanan). Periklanan adalah bentuk komunikasi nonpersonal terkait produk barang atau jasa yang biaya operasionalnya dibebankan kepada lembaga atau perusahaan sponsor tersebut. keuntungan dari strategi promosi periklanan ini adalah jangkauannya yang luas, dapat menjangkau khlayak ramai dalam waktu yang singkat. Dalam program sahabat wakaf, lembaga Gerakan Wakaf Indonesia (GWI) melakukan promosi melalui periklanan dengan memanfaatkan media iklan yang ada, seperti membagikan brosur program sahabat wakaf, memasang spanduk dijalanan yang strategis, posting brosur di media sosial misalnya Instagram, Facebook, Twitter, Youtube. Tujuan dari dilakukannya kegiatan promosi program sahabat wakaf melalui periklanan antara lain : (a) untuk memberitahu kepada mahasiswa atau mahasiswi mengenai segala sesuatu yang berhubungan dengan program sahabat wakaf, (b) memberikan indormasi mengenai manfaat dan keunggulan dari program sahabat wakaf, (c) mempengaruhi

\footnotetext{
${ }^{22}$ Bustami; Muhammad Luthfi hakim, "Strategy of Cash Development on Gerakan Wakaf Produktif at baitulmaal Munzalan Indonesia Foundations in Digital Era", at-Tahrir: Jurnal Pemikiran Islam, 20, 1(2020): 34.

${ }^{23}$ Ah. Ali Arini, Wawancara (25 Februari 2021). Penaseha Gerakan Wakaf Indonesia.
} 
mahasiswa/mahasiswi supaya mau bergabung menjadi bagian dari sahabat wakaf, (d) untuk mengingatkan bahwa program sahabat wakaf memberikan praktik pembelajaran yang akan bermanfaat dikemudian hari, (e) Untuk mengingatkan calon sahabat wakaf bahwa dia juga bisa berwakaf. ${ }^{24}$

Biaya dari kegiatan periklanan nantinya akan dibebankan kepada anggota sahabat wakaf dengan tujuan untuk menekan biaya yang dikeluarkan oleh lembaga Gerakan Wakaf Indonesia. Pada pelaksanaan kegitan periklanan, lembaga dan tim wakaf dari lembaga Gerakan Wakaf Indonesia akan menjadi suvervisor dan memfalisitasi kelancaran pelaksanaan training calon sahabat wakaf yang digelar setiap bulannya.

Media periklanan yang digunakan oleh lembaga GWI untuk melakukan kegiatan periklanan antara lain : a) mencetak brosur terkait program sahabat wakaf dan menyebarkannya ditempat yang berpotensial, b) memasang spanduk besar di jalan-jalan yang strategis, c) memasang papan iklan supaya capaian targetnya lebih meluas lagi, dan d) memasang iklan melalui berbagai macam media yang ada seperti iklan program sahabat wakaf di media cetak (majalah), media elettronik, dan media massa. ${ }^{25}$

Dari strategi promosi periklanan yang harus diperhatikan selain biaya antara lain; a) menetapkan sasaran atau pembeli yang menjadi target pemasaran, b) menganalisis seberapa besar jangkauan dari media iklan yang dipakai serta sesuai dengan tujuan pemasaran produk barang atau jasa yang ditawarkan, c) menilai apakah sifat media iklan yang akan digunakan sesuai dengan tujuan yang diinginkan. ${ }^{26}$

Kedua Personal selling atau sering disebut juga sebagai penjualan pribadi. Strategi penjualan pribadi adalah strategi promosi dimana penjual akan melakukan interaksi secara langsung dengan calon pembeli. Penjualan pribadi merupakan bentuk komunikasi secara personal kepada pembeli mengenai produk barang atau jasa yang ditawarkan. Jadi untuk melakukan kegiatan ini lembaga Gerakan Wakaf Indonesia melakukan dakwah atau seminar di universitas perguruan tinggi yang sudah bekerjasama untuk menyampaikan secara langsung mengenai program sahabat wakaf. Kegiatan penjualan pribadi ini adalah cara yang paling ampuh untuk melakukan promosi program sahabat wakaf karena dengan ini kita dapat mengetahui karakteristik calon sahabat wakaf secara langsung. Selain itu, strategi promosi penjualan pribadi memiliki

\footnotetext{
${ }^{24}$ Misbahul Huda, Wawancara (Sidoarjo, 24 Februari 2021)

${ }^{25}$ Misbahul Huda, Wawancara (Sidoarjo, 24 Februari 2021)

${ }^{26}$ Ah. Ali Arifin, Wawancara (Sidoarjo, 25 Februari 2021)
} 
kesamaan dengan strategi promosi periklanan, keduanya sama-sama mengeluarkan biaya operasional yang tinggi.

Jika promosi periklanan mengeluarkan biaya untuk membayar media untuk mengiklankan produknya, sedangkan promosi penjualan pribadi mengeluarkan biaya untuk membayar sales yang terjun ke lapangan untuk memasarkan produknya. perbedaan diantara kedua strategi promosi tersebut terletak dari segi bentuk promosi mengenai produk yang ditawarkan, strategi promosi periklanan memprosikan produknya secara tidak langsung melalui media iklan, sedangkan promosi pejualan pribadi mempromosikan produknya secara langsung ke target pasar yang potensial.

Ketiga, Promosi penjualan. Strategi promosi ini hampir mirip dengan penjualan secara langsung. Strategi ini biasa disebut dengan jemput bola, artinya penjual terjun langsung ke lapangan untuk mempromosikan produk jualannya. Promosi penjualan merupakan kegiatan mempromosikan atau memberikan informasi terkait program sahabat wakaf kepada calon sahabat wakaf. Untuk meningkatkan penjualan dan jumlah pelanggan dalam waktu yang singkat merupakan tujuan dari promosi penjualan. Promosi pejualan terkait program sahabat wakaf ini, lembaga Gerakan Wakaf Indonesia (GWI) merencanakan atau memformulasikan antara lain : melakukan seminar dan membuka stand program sahabat wakaf di event-event khusus yang berkaitan dengan syariah guna mengajak para mahasiswa atau mahasiswi untuk menjadi sahabat wakaf, kemudian memberikan informasi tentang program sahabat wakaf untuk menarik perhatian calon sahabat wakaf agar mau bergabung, serta memberikan penjelasan manfaat dari program sahabat wakaf.

Keempat, Publicity (Publisitas) dan hubungan masyarakat merupakan aktivitas atau kegiatan yang tidak bertemu secara langsung dengan calon pembeli, tetapi berupa berita komersial di media massa untuk mempromosikan produk atau melindungi citra suatu lembaga. Strategi promosi ini memiliki kesamaan dengan promosi periklanan, keduanya sama-sama promosi yang dilakukan secara tidak langsung atau nonpersonal terkait barang atau jasa yang ditawarkan. Keuntungan melakukan strategi promosi publisitas dan hubungan masyarakat ini terletak pada biayanya, karena dalam kegiatan ini lembaga tidak mengeluarkan dan membayar media massa untuk dijadikan sebagai sarana melakukan promosi. ${ }^{27}$

Promosi publisitas memiliki peranan yang sangat penting di sebuah perusahaan dalam membangun citra baik di masyarakat. Dengan

${ }^{27}$ Ah. Ali Arifin, Wawancara (Sidoarjo, 25 Februari 2021) 
strategi ini lembaga Gerakan Wakaf Indonesia dapat memanfaatkan dengan baik media massa untuk membangun citra yang baik di masyarakat, jika lembaga dapat memiliki citra yang baik dimata masyarakat maka secara tidak langsung akan memperkuat nilai jual program sahabat wakaf dan bisa menarik mahasiswa atau mahasiwi untuk bergabung menjadi bagian dari sahabat wakaf.

Strategi promosi publisitas ini adalah salah satu cara promosi yang sering digunakan oleh lembaga lain untuk melakukan demonstrasi online lalui media massa. Selain itu, strategi adalah strategi promosi yang paling efisien karena biaya yang tidak terlalu besar, tidak butuh kinerja orang untuk melakukan promosi produk. Dengan strategi ini lembaga gerakan wakaf indonesia dapat menjangkau terget pemasaran secara luas, karena sebagian besar penduduk di indonesia mayoritas memiliki handphone dan menggunakan media massa apalagi di kalangan mahasiswa atau mahasiswi yang masih berada di usia millenial pastinya tidak lepas dan aktif didunia maya. Kesempatan besar ini dapat dimanfaatkan oleh lembaga Gerakan Wakaf Indonesia (GWI) untuk melakukan promosi dengan giat di media massa seperi instagram, facebook, dan twitter untuk menarik perhatian pengguna media massa agar mau ikut bergabung menjadi bagian dari sahabat wakaf. ${ }^{28}$

Kelima, Penjualan Langsung (Direct Marketing). Penjualan langsung adalah strategi promosi yang dilakukan secara langsung dengan konsumen yang sudah ditargetkan. Keunggulan dari strategi promosi ini adalah tidak perlu adanya tenaga penjual atau sales untuk memasarkan produk barang atau jasa yang akan ditawarkan, tetapi bisa melakukan promosi melalui media perantara seperti telepon (Tele Marketing) dan surat. Strategi promosi ini sedikit berbeda target konsumennya, berbeda dengan promosi penjualan pribadi yang langsung menargetkan khalayak ramai, strategi promosi penjualan langsung untuk target konsumen yang akan dipengaruhi sudah tersusun secara sistematis dan dihubungi melalui media perantara telepon atau surat. Di lembaga Gerakan Wakaf Indonesia melakukan strategi ini dengan menghubungi unit kampus yang memiliki tujuan relevan dengan program sahabat wakaf misalnya Griya derma UINSA. Lembaga GWI melakukan kerja sama dengan Griya derma dan mengajak anggota Griya Derma untuk ikut bergabung dengan sahabat wakaf.

${ }^{28}$ Misbahul Huda, Wawancara (Sidoarjo, 24 Februari 2021) 


\section{Pelaksanaan Strategi Promosi Lembaga Gerakan Wakaf Indonesia}

Pelaksanaan strategi promosi adalah proses kelanjutan setelah merencanakan atau memformulasikan kegiatan promosi program sahabat wakaf di berbagai kampus ternama yang ada, sejauh ini lembaga Gerakan Wakaf Indonesia sudah melakukan kegiatan promosi program sahabat wakaf di Uninersitar Airlangga, Universitas Islam Negeri Sunan Ampel, Universitas Nahdlatul Ulama dan Universitas Trunojoyo Madura. Pelaksanaan strategi promosi program sahabat wakaf dibutuhkan manajerial yang ahli dan baik, lembaga Gerakan Wakaf Indonesia memiliki berbagai tahapan guna mencapai tujuannya agar mendapat calon sahabat wakaf yang memenuhi target. Pelaksanaan strategi promosi ini sesuai dengan empat bauran promosi yang telah diformulasikan sebelumnya. ${ }^{29}$

Periklanan, memberitahukan tentang program sahabat wakaf, manfaat yang akan diterima saat bergabung menjadi sahabat wakaf, dan keunggulan dari sahabat wakaf melalui media iklan yang sudah diformulasikan seperti brosur, pamflet, instragram, facebook, twitter, whatsapp, spanduk dan banner. Membujuk para mahasiswa atau mahasiswi untuk bergabung dan menjadi sahabat wakaf. Serta mengingatkan dan menyadarkan bahwa calon sahabat wakaf juga bisa berwakaf sesuai dengan kemampuannya. Karena berwakaf tidak hanya diperuntukkan untuk orang kaya saja semua orang bisa melakukannya.

Personal selling atau sering disebut penjualan langsung. Dengan kegiatan ini, lembaga Gerakan Wakaf Indonesia mendatangi secara Langsung universitas yang akan diadakan seminar tentang program sahabat wakaf. Kegiatan ini yang sering dilakukan oleh lembaga Gerakan Wakaf Indonesia untuk melakukan kegiatan promosi program sahabat wakaf, karena dengan promosi secara langsung dapat memberi penjelasan secara detail terkait program sahabat wakaf, mengetahui keluhan dari mahasiwa/i terkait program dan melihat secara langsung respon yang diberikan oleh para mahasiswa atau mahasiswi di universitas yang dikunjungi. ${ }^{30}$

Promosi penjualan, dalam kegiatan ini lembaga Gerakan Wakaf Indonesia melakukan pameran disetiap event khusus, karena melalui strategi ini kita dapat melakukan promosi terkait program sahabat wakaf kepada setiap mahasiswa atau mahasiwi yang datang ketempat pameran.

Publisitas dan hubungan masyarakat, strategi ini digunakan karena banyak mahasiswa atau mahasiswi yang cenderung tingkat kesadaran untuk berwakaf dan pengetahuan tentang wakaf juga berkurang. Melalui

\footnotetext{
${ }^{29}$ Misbahul Huda, Wawancara (Sidoarjo, 24 Februari 2021)

${ }^{30}$ Ah. Ali Arini, Wawancara (Sidoarjo, 25 Februari 2021)
} 
kegiatan ini lembaga Gerakan Wakaf Indonesia lebih menyampaikan pesan berupa berita, seperti sedang mendengarkan sebuah berita tentang wakaf, jadi potensi wakaf yang kurang maksimal, dapat menimbulkan keinginan untuk berwakaf dan bergabung menjadi sahabat wakaf. Media yang digunakan untuk strategi promosi pbulisitas adalah media massa seperti facebook, twitter, instragram, dan whatssapp. Cara ini sangat efisien dan efektif, selain mengikuti perkembangan zaman yang modern dan hampir seluruh mahasiswa/mahasiwi menggunakan media massa dalam kesehariannya.

\section{Evaluasi strategi promosi Gerakan Wakag Indonesia}

Evaluasi strategi promosi merupakan tahapan akhir dari strategi promosi program sahabat wakaf yang dilakukan oleh lembaga Gerakan Wakaf Indonesia. Proses evaluasi strategi promosi program sahabat wakaf merupakan bagian yang penting saat melakukan kegiatan promosi, karena kegiatan evaluasi ini dilakukan dengan tujuan untuk mengetahui kekurangan atau kelemahan selama proses promosi dialaksanakan, sehingga dapat segera dilakukan tindakan dengan cara meningkatkan kualitas promosi apabila akan melakukan kegiatan promosi lagi. Evaluasi strategi promosi sahabat wakaf dilakukan sesuai dengan bauran pemasaran yang sudah diformulasikan sebelumnya seperti periklanan, personal selling atau penjualan pribadi, promosi penjualan, publisitas dan hubungan masyarakat.

Periklanan, lembaga melakukan pengecekan apakah iklan yang telah dibuat sudah mencakup semua tentang program sahabat wakaf, memperhatikan tata bahasa yang digunakan apakah sudah tepat dan dapat dipahami oleh pembaca, serta memperhatikan media yang dipilih apakah sudah tepat dan memberikan hasil yang maksimal dalam kurun waktu tertentu. ${ }^{31}$

Penjualan pribadi atau personal selling, evaluasi dalam kegiatan ini biasanya dilakukan oleh koordinator yang bertanggung jawab disetiap kelompok anggota sahabat wakaf di lembaga Gerakan Wakaf Indonesia. Evaluasi dalam kegiatan penjualan langsung ini hal yang dipertimbangkan antara lain; biaya yang dikeluarkan dan perilaku proses penjualan. Biaya proses penjualan pribadi relatif kecil, sehingga proses penjualan langsung lebih efektif dari sisi biaya operasional. Sedangkan perilaku proses penjualan pribadi, anggota sahabat wakaf dianjurkan melakukan kegiatan ini dengan cara-cara yang santun dan sesuai syariah, terutama dalam proses seleksi yang dilakukan untuk calon sahabat wakaf.

\footnotetext{
${ }^{31}$ Misbahul Huda, Wawancara (Sidoarjo, 24 Februari 2021)
} 
Promosi penjualan, dalam evaluasi promosi penjualan ini biasanya dilakukan bersama dengan tim yang sudah dibentuk. Secara strategi promosi, proses penjualan yang dilakukan akan lebih maksimal lagi jika anggota sahabat wakaf memaksimalkan komunikasi, kreativitas insentif dan bergerak cepat melakukan ajakan kepada mashiswa atau mahasisiwi untuk ikut bergabung menjadi bagian daru sahabat wakaf. ${ }^{32}$

Publisitas dan hubungan masyarakat, dalam proses evaluasi ini tidak semua anggota wakaf yang melakukannya, jumlah penghimpuanan yang memang sulit diukur, dikarenakan proses kegiatan ini dilakukan bersama dengan kegiatan promosi yang lain. Penjualan Langsung (Direct Marketing), evaluasi dalam kegiatan promosi ini dilakukan langsung oleh tim sahabat wakaf yang sudah dibentuk khusus untuk mengkoordinasi strategi promosi ini.

\section{Kesimpulan}

Dari hasil penelitian dan diskusi diatas, maka dapat ditarik kesimpulan sebagai berikut yaitu: 1) Lembaga Gerakan Wakaf Indonesia dalam melaksanakan strategi promosi program wakaf pendamping yaitu dengan menginformasikan dan mengenalkan program pendamping wakaf ini melalui media cetak (brosur, pamflet). dan majalah) dan internet (Instagram, Twitter, Facebook dan WhatsApp), 2) dalam melaksanakan strategi promosi program wakaf wakaf, lembaga Gerakan Wakaf Indonesia bekerjasama dengan berbagai kampus ternama dengan mengadakan seminar tentang wakaf sahabat, 3) Promosi yang telah dirumuskan dan dilaksanakan berjalan dengan cukup baik, walaupun masih ada beberapa faktor yang menjadi penghambat namun hal ini dapat menjadi catatan bagi lembaga Gerakan Wakaf Indonesia dalam menjalankan strategi promosi kedepannya.

\section{Daftar Pustaka}

Ali, Khalifah Muhammad; Meida Yuliani; Sri Mulatsih; Zaki Abdullah, "Aspek-Aspek Prioritas Manajemen Wakaf di Indonesia", ALFALAH: Journal of Islamic Economics, 3, 1(2018).

Bisri, Cik Hasan. Pilar-Pilar Penelitian Hukum Islam dan Pranata Sosial. Jakarta : Grafindo Persada, 2004.

Bungin, Burhan. Penelitian Kualitatif : Komunikasi, Ekonomi, Kebijakan Publik, dan Ilmu Sosial lainnya. Jakarta: Kencana Prenada Media Group.

Bustami; Muhammad Luthfi hakim, "Strategy of Cash Development on Gerakan Wakaf Produktif at baitulmaal Munzalan Indonesia Foundations in Digital Era", at-Tahrir: Jurnal Pemikiran Islam, 20, $1(2020)$.

\footnotetext{
${ }^{32}$ Misbahul Huda, Wawancara (Sidoarjo, 24 Februari 2021)
} 
Cizakca, M. "Ottoman Cash Waqfs Revisted: the Cas of Bursa 1555-1823", Journal of Economic and Social History of the Orient, 38, 3(2013).

Creswell, John W. Research Design, Qualitative, Quantitative and Mixed Methods Approaches, Trans. Yogyakarta: Pustaka Pelajar, 2016.

Dahlan, Rahmat. "Analisis Kelembagaan Badan Wakaf di Indonesia", ESENSI: Jurnal Bisnis dan Manajemen, 6, 1(2016).

Faisal, Muhammad. "Sikap, Norma Subyektif, Religuisitas dan Partisipasi terhadap Wakaf Tunai, Li Falah: Jurnal Studi Ekonmi dan Bisnis Islam, 4,1(2019).

Faturahman, Burhanudin Mukhamad. "Kepemimpinan dalam Budaya Organisasi", Madani: Jurnal Politik dan Sosial Kemasyarakatan, 10, 1(2018).

Ghozilah, Umi; Eka Khumaidatul Khasanah, "Manajemen Wakaf Produktif dalam Pemberdayaan di KSPPS BMT Bina Umat Sejahtera Lasem Rembang", Management and Werment Journal, 2, 2(2020).

Hiyanti, Hida; Indria Fitri Afiyana; Siti Fazriah, "Potensi dan Realisasi Wakaf Uang di Indonesia Tahun 20154-2018", Jurnal Ilmiah MEA (Manajemen, Ekonomi, E Akuntansi), 4, 1(2020).

Medias, Fahmi. "Bank Wakaf: Solusi Pemberdayaan Sosial Ekonomi Indonesia", Indonesian Journal of Islamic Literature and Muslim Society, 2,1(2017).

Meleong, Lexy J. Metodologi Penelitian Kualitatif Edisi Revisi, Cet. Ke-22. Bandung : PT Remaja Rosdakarya, 2006.

Misbahul Huda, Wawancara (Sidoarjo, 24 Februari 2021)

Nasution, Lokot Zein; Diba Anggraini Aris, "Konstruksi Pengembangan Wakaf Saham dalam Rangka Mengoptimalkan Potensi Wakaf Produktif di Indonesia", Islamic Circle, 1,1(2020).

Rusydiana, Aam; Solihah S. Rahayu, "Bagaimana Strategi Pengembangan Wakaf Tunai di Indonesia", Jurnal Ekonomi dan Bisnis Islam, 5,1(2019).

Sugiyono, Metode Penelitian Kuantitatif Kualitatif dan $R \mathcal{E} D$. Bandung: Alfabeta, 2014.

Wahyu, Agung Minto; Navillah Laila Wardani, “Wakaf Uang Digital untuk Milenial: Pemanaatan Bonus Demografi Melalui Aplikasi Wakaf Uang Digital untuk Mengembangkan Industri UMKM Halal", el-Aswaq, 1, 1(2020).

Yuliafitri, Indri; Arie Indra Rivaldi, "Pengaruh Penerapan Prinsip-Prinsip Good Governance dan Promosi terhadap Penerimaan Wakaf Tunai (pada Lembaga Pengelola Wakaf di Indonesia)", Jurnal InFestasi, 13, 1(2017). 
Ah. Ali Arifin, Wawancara (25 Februari 2021)

Ali Hamdan, Wawancara (Sidoarjo, 25 Februari 2021).

https://gerakanwakaf.id/. 